Alexandrian Cosmopolitanism 
This page intentionally left blank 


\section{Alexandrian Cosmopolitanism}

A N A R C H I E

Hala Halim

FORdham university press New York 2013 


\section{$\mathrm{mL}$}

THIS BOOK IS MADE POSSIBLE BY A COLLABORATIVE GRANT FROM THE ANDREW W. MELLON FOUNDATION.

\section{Copyright @ 2013 Fordham University Press}

All rights reserved. No part of this publication may be reproduced, stored in a retrieval system, or transmitted in any form or by any means-electronic, mechanical, photocopy, recording, or any otherexcept for brief quotations in printed reviews, without the prior permission of the publisher.

Fordham University Press has no responsibility for the persistence or accuracy of URLs for external or thirdparty Internet websites referred to in this publication and does not guarantee that any content on such websites is, or will remain, accurate or appropriate.

Fordham University Press also publishes its books in a variety of electronic formats. Some content that appears in print may not be available in electronic books.

Library of Congress Cataloging-in-Publication Data

Halim, Hala.

Alexandrian cosmopolitanism : an archive /

Hala Halim. - First edition. pages $\mathrm{cm}$

Includes bibliographical references and index. ISBN 978-0-8232-5I76-6 (cloth : alk. paper) I. Alexandria (Egypt)-In literature.

2. Cosmopolitanism in literature. 3. European literature-I9th century-History and criticism. 4. European literature-2oth century-History and criticism. I. Title.

$\mathrm{PN}_{5} 6.3 . \mathrm{A}_{42} \mathrm{H}_{35} \quad 20 \mathrm{I}_{3}$

$809^{\prime} .9335862 \mathrm{I}$-dc23

Printed in the United States of America

I5 I4 I3 54432 I

First edition 
To Youssef Halim

and

to the memory of Amal Halim and Marie Yassa 
This page intentionally left blank 